\title{
THE APPLICATION OF ATHLETICS TOOLS IN DUE TO DEVELOP SPEED OF SECONDARY SCHOOL CHILDREN
}

\author{
Olena Khanikiants \\ Lviv State University of Physical Culture named after Ivan Bobersky, Ukraine \\ Volodymyr Konestyapin \\ Lviv State University of Physical Culture named after Ivan Bobersky, Ukraine \\ Olga Rymar \\ Lviv State University of Physical Culture named after Ivan Bobersky, Ukraine \\ Marta Yaroshyk \\ Lviv State University of Physical Culture named after Ivan Bobersky, Ukraine

\section{Nataliya Sorokolit} \\ Lviv State University of Physical Culture named after Ivan Bobersky, Ukraine
}

\begin{abstract}
The research is dedicated to searching of new tools for higher effectiveness of the application of athletic tools to develop speed of secondary school children. The goal of research is to prove theoretically and test experimentally the program for speed development of secondary school children (11-12 years) with priority use of athletic tools.

To realize the goal such methods were applied: scientific theoretical, pedagogical observation, experiment, mathematical statistics methods. Boys are from 6 grades (11-12 years old) have participated. Pupils belong to main medical group. The results. There was elaborated and experimentally proved the program's effectiveness. We have got statistically significant difference $(p<0.05)$, better results from experimental group of performing control exercises: "30m run (sec)", "30m run from place (sec)", "run at the place during $5 \mathrm{sec}$ (number of movements)". One exercise has got better result from control group - "run at the place during 5 sec (number of movements)". We have performed evaluation of students' speed development before and after the experiment. Amount of pupils with high level of competence has grown in exercises " $30 \mathrm{~m}$ run (sec)" for $13.3 \%$, "60m run (sec)" for 20\%, "shuttle run $4 \times 9 \mathrm{~m}$ (sec)" for $6.7 \%$, “long jump from place $(\mathrm{cm})$ for $13.3 \%$.
\end{abstract}

Keywords: athletics, competence level (achievement level), program of speed development, secondary school children. 
Khanikiants et al., 2021. The Application of Athletics Tools in Due to Develop Speed of Secondary School Children

\section{Introduction}

The development of important skills is building during studying in the secondary school, the level of physical health is forming there (the development of bone and muscle tissue, organs, vestibular apparatus, motor reactions etc.)

(Dubogaj, Pangelov, Frolova, \& Gorbenko, 2001; Fedonjuk et al., 2007; Rymar, \& Khanikiants, 2020). The interconnection of development of speed of integral movements and speed-power qualities is the special characteristics for 11-12 years old teenagers (Krucevich, 2008). So, the important factor for achievement of those opportunities, that are genetically laid down, in the speediness presentation is the improvement of its components in the most favorable periods of children's age development.

The analysis of theory and school work practice in Ukraine shows that it is important to be ruled by principles of natural sciences - anatomy, physiology, pedagogics, psychology etc. during the process of planning of physical education system in the borders of school course. The special attention should be directed on secondary school children, who have significant changes in motor and vegetative functions and the development of speediness has a special meaning because of its level influences the improvement of other motor qualities (Drobin, 1990; Sorokolit, Shyan, Lukjanchenko, \& Turchyk, 2017; Khanikiants, Konestyapin, \& Goliney, 2019). The process of increase of effectiveness for improvement mechanisms of the educational processes is important also because young people generally do not have appropriate skills and appropriate level of development of motor qualities in order to form and keep its own health after they finish studying in secondary school and continue studying in universities (Zavydivska, Zavydivska, Khanikiants, \& Rymar, 2017).

The athletics exercises have slightly different influence on the children's body. Performing of athletic exercises has positive impact not only on all motor skills but also improve joint mobility, promote education of agility, memory, attention and volitional skills and fast speed run has higher requirements to cardiovascular and breath systems (Konestyapin \& Viter, 2008; Halajdzhi, Jagotin, Lagovs'ka, \& Capenko, 2018).

Athletics is a huge part of "Studying program from physical culture" for general education establishments in Ukraine. Thus, the option module "Athletics", on the basis of calculation of material-technical base of the establishment, regional sport traditions and staffing, as a rule, forms invariable (obligatory) component for pupils from 5-9 classes.

However, even though athletics is different by various natural tool and forms of classes performing, the experience of teachers from Ukrainian school confirms that traditional system, applying of athletics exercises (monotonous 
exercises, long athletic walking, run and crosses), sharply decrease the effectiveness of its implementation and pupils' interest towards classes.

The information above reveals that issue of determination of physical education classes content in school course needs further elaborations about organizational and methodic basis of using athletic tools on physical education classes in due to develop speediness and to form motivation and interest towards athletic classes among secondary school children.

The goal of the research is to justify theoretically and prove experimentally the program of development of speediness among secondary school children (11-12 years) with priority use of athletics tools.

\section{Methodology}

The complex of methods that are widely used among specialists in the branch of physical education was applied in the work. In due to theoretically justify author program general scientific theoretical methods were used in due to those, the results were analyzed from previous investigations of specialists from theory and methodic of physical education of teenagers. However, it was determined that: the variations of speediness are not enough connected between each other, the elementary forms of speediness are little amenable to be improved, but there is possibility of a significant progress in the result of special training in development of complex forms of speediness presentation, as far as the complex speed qualities are dependent from a lot of factors, that can be improved (Fedonjuk et al., 2007; Halajdzhi et al., 2018); tools to develop speediness have to be relatively easy according to coordination, diverse and adequative according to exact speediness presentation, and its performing should be with a maximum and near maximum speed (Shyan, 2004; Krucevich, 2008; Sorokolit et al., 2017); the effective methods to develop speediness are: repeated methods, gaming and competitive methods (Linec', 1997; Shyan, 2004; Krucevich, 2008); main methodic mistakes during the process of speediness development are: lack of diversification of training impacts, sharp increase in volume and intensification of speed exercises, insufficient level of learning of the exercises techniques; overloading of particular branches of musculoskeletal system; the performing of speediness exercises with the background of physical, psychological or coordination fatigue (Linec', 1997; Shyan, 2004).

Pedagogical observation and pedagogical experiment were performed on the basis of general educational establishments (Novoyavorivsk, Ukraine) on the physical education classes with boys (11-12 years old). The program has lasted during seven weeks (April - May 2019) and has covered 21 lessons. All pupils are the part of a main medical group according to health condition, so the physical preparation is performed with these pupils according to the full content 
Khanikiants et al., 2021. The Application of Athletics Tools in Due to Develop Speed of Secondary School Children

of studying program and taking into account individual specifics of development. Pupils were divided in the beginning of the experiment into 2 groups - the control $(n=32)$ and the experimental $(n=31)$ groups.

The control group (CG) was doing classes according to generally approved methodic of optional module "Athletic" (Fizichna kul'tura v shkoli: navchal'na programa, 2018). The experimental group (EG) was doing classes according to author program of the development of speediness of secondary school children (11-12 years) with priority use of athletic tools. The implementation of author program did not contradict and did not disturb general requirements according to the goal, tasks and structure of studying process that are constructed for the discipline "Physical development" for pupils from 5-9 classes of general education schools.

Statistical analysis. The data we have got are processed with the help of Microsoft Office XP programs and using the pack for statistical processing "Statistica 6". We have calculated mean value $(\bar{X})$, standard deviation $( \pm \sigma)$, and Student t-criteria.

\section{Results and Discussion}

The elaborated program fits humanistic and health strengthening direction, teaching a need in physical development of children, providing essential level of physical preparation, in particular it is the development of speediness.

The program includes exercises that are maximally effective, adapted and recommended by specialists in the direction of physical education and athletics in due to develop speediness in the process of physical preparation (Alabin, Zub, \& Mishhenko, 1993; Kushmeljuk \& Kushmeljuk, 2007; Semenov, Osadchenko, Maєvs'kij, \& Il'chenko, 2014; Mandiuk, Yaroshyk, \& Litkevich, 2014). The program consists of 21 lessons during seven weeks.

The elaborated program promotes:

- Optimization of studying process using elements of innovative studying methods;

- Providing of differentiated approach according to organization of studying process, taking into account health condition, level of physical development, motor preparation and pupil's gender, their motives and interests towards doing physical exercises;

- $\quad$ Speediness development, increase of level of physical preparation in general, strengthening of musculoskeletal system and improvement of physical and mental effectiveness. The experimental group includes 3 parts. The first one includes exercises, mainly with speediness orientation, the second one includes speediness exercises and speed- 
power direction, the third one - exercises of general physical preparation;

- Increasement of achievement level (competence) of pupils.

The specifics of author program are:

- There was determined the optimal ratio of tools with various orientations, the load range; there were chosen adequate and effective methods in due to achieve the goals using classes tools. In general, there were given $30 \%$ of tools for general physical preparation, $20 \%$ for maintaining technique of performing athletic exercises, $50 \%$ for developing of speediness and speed-power components.

- $\quad$ There were used a wide assortment of athletic exercises, in particular sprinter run in short distances from 10 to $60 \mathrm{~m}$ (in maximal tempos from different starting positions in support with hands from the wall in maximal tempo, with acceleration, "on the spot", with variable speed in borders $70-100 \%$ out from individual possible maximal value, in eased or complicated conditions etc.). Despite the wide use of sprinter run, the program included exercises for development of speed power, speed endurance and explosive force. The reaching of tasks of general physical preparation and maintaining of technique of performing athletic exercises was partially performed using of speediness development tools and speed-power components.

- $\quad$ The module "Athletics" was planned in such way so restorative micro cycles can be changed by micro-cycles of speed and speed-power orientation. It helped to avoid the uniformity in using of forms and training tools and prevent occurrence of progressive fatigue;

- There are widely used exercises for coordination development, improvement of joint mobility, muscle elasticity, stretching of muscles, joints and tendons in preparation and closing parts of the lesson;

- $\quad$ A lot of chosen exercises in the program were used as the elements of various motor games or in form of relay in order to reach optimal success of studying activity. This promotes increase of emotional background of the lesson, motivation towards physical education classes, kid's desire to improve their physical qualities and motor skills. Active games and relays, that are used in the elaborated program, answer lessons' tasks and are performed in the main part of the lesson;

- We have created the correct psychological motivation in the process of the lesson. We have applied, for example, various competitive situations, we have chosen competitors relatively with the same weight category and level of development of motor qualities in order 
Khanikiants et al., 2021. The Application of Athletics Tools in Due to Develop Speed of Secondary School Children

to perform game elements; we have provided information about the results of performed tasks regularly etc. Such approaches provide the full realization of functional potential of pupils.

There were mainly used repetitive, interval, game and competitive methods in the elaborated program.

After the experiment the statistically reliable $(\mathrm{p}<0,05)$ improvement was noticed among pupils from the experimental group in the result of performing of such exercises as " $30 \mathrm{~m}$ run", " $30 \mathrm{~m}$ run from the spot" and "run at the spot during 5sec". The positive dynamics was noticed in the results of other control exercises, though we cannot testify that it is statistically reliable (Table 1). The results we have got during control lessons support specialists' thoughts that children with age from 7-8 years old to 11-12 years old are best developed by motor reactions and by frequency of movements (Linec', 1997; Shyan, 2004; Krucevich, 2008).

Table 1 Average Values ( $\bar{X} \pm \sigma)$ of Results of Control Exercises Performed by Pupils Before and After the Experiment

\begin{tabular}{|c|c|c|c|c|c|c|}
\hline \multirow{3}{*}{$\begin{array}{l}\text { Control } \\
\text { exercises }\end{array}$} & \multicolumn{6}{|c|}{ Groups } \\
\hline & CG* & CG** & \multirow{2}{*}{$\mathrm{p}$} & EG* & EG** & \multirow{2}{*}{$\mathrm{p}$} \\
\hline & \multicolumn{2}{|c|}{$(n=32)$} & & \multicolumn{2}{|c|}{$(n=31)$} & \\
\hline $30 m$ run (sec) & $6.42 \pm 0.55$ & $6.33 \pm 0.55$ & $>0.05$ & $6.39 \pm 0.53$ & $6.19 \pm 0.59$ & $<0.05$ \\
\hline $60 \mathrm{~m}$ run (sec) & $11.1 \pm 0.68$ & $11.06 \pm 0,71$ & $>0.05$ & $11.14 \pm 0.73$ & $11.03 \pm 077$ & $>0.05$ \\
\hline $\begin{array}{l}\text { 30m run from } \\
\text { the spot (sec) }\end{array}$ & $5.88 \pm 0.25$ & $5.8 \pm 0.22$ & $>0.05$ & $5.86 \pm 0.25$ & $5.68 \pm .26$ & $<0.05$ \\
\hline $\begin{array}{l}\text { run at the spot } \\
\text { during } 5 \\
\text { seconds } \\
\text { (movements } \\
\text { quantity) } \\
\end{array}$ & $20.46 \pm 1.79$ & $21.1 \pm 1.62$ & $<0.05$ & $20.47 \pm 1.78$ & $22.53 \pm 1.78$ & $<0.05$ \\
\hline $\begin{array}{c}\text { shuttle run } 4 \times 9 \\
\text { m (sec) }\end{array}$ & $12.07 \pm 0.54$ & $11.9 \pm 0.56$ & $>0.05$ & $12.09 \pm 0.59$ & $11.87 \pm 0.61$ & $>0.05$ \\
\hline $\begin{array}{l}\text { long jump from } \\
\text { the place }(\mathrm{cm})\end{array}$ & $\begin{array}{c}150.66 \pm 15 . \\
91\end{array}$ & $151.53 \pm 17.90$ & $>0.05$ & $\begin{array}{c}150.2 \pm 17.9 \\
2 \\
\end{array}$ & $\begin{array}{c}151.8 \pm 18.3 \\
6\end{array}$ & $>0.05$ \\
\hline
\end{tabular}

Note: $\mathrm{CG}^{*}$ - the control group before the experiment; $\mathrm{CG}^{* *}$ - the control group after the experiment; EG* - the experimental group before the experiment; EG** - the experimental group after the experiment.

Even though, the studying program for general education schools (Fizichna kul'tura v shkoli: navchal'na programa, 2018) recommends to use exercise "60m run (sec)" as a control one, we see that quantitate indicators of results of performing this exercises did not change significantly neither among pupils from the EG, nor among pupils from the CG. This confirms specialists' thoughts 
(Shyan, 2004; Khanikiants, Rymar, \& Konestyapin, 2020), that it is important to choose shorter distances and with a previous run up as a control exercise according to development of speediness for pupils this age. These exercises, for example, are as follows: " $20 \mathrm{~m}$ run from a spot (sec)" or even " $10 \mathrm{~m}$ run from a spot (sec)”.

As far as four out from six of control exercises, that we have used, are recommended by Studying program from Physical education for 5-9 classes of general educational establishments "Physical culture in school" (Fizichna kul'tura v shkoli: navchal'na programa, 2018), we have had an opportunity to determine change in pupils' levels of competence.

We can see in the table 2 that quantity of pupils with high level of competence has grown after implementation of author program in such exercises: " $30 \mathrm{~m}$ run" - in the EG for $19.4 \%$, in the CG - for $9.4 \%$; " $60 \mathrm{~m}$ run" in the EG for $12.9 \%$, in the CG - just for $6.3 \%$; "Shuttle run $4 \times 9 m$ " - the improvement was as in the EG so in the CG equally; "long jump from the place" - in the AG for $16.1 \%$, in the CG the level of competence did not change.

Table 2 The Ratio of Changes of High Level of Competence by Pupils from the Experimental and Control Groups (after the experiment)

\begin{tabular}{|c|c|c|}
\hline Control exercises & The EG pupils(\%) & The CG pupils(\%) \\
\hline “30m run (sec)” & $19.4 \%$ & $9.4 \%$ \\
\hline “60m run (sec)” & $12.9 \%$ & $6.3 \%$ \\
\hline “shuttle run 4x9m (sec)” & $6.5 \%$ & $6.3 \%$ \\
\hline “long jump from the place (cm)” & $16.1 \%$ & No changes \\
\hline
\end{tabular}

Out from table 3 we can see that after the implementation of author program there become less pupils that demonstrate low level of competence according to results of performing such exercises: "30m run" - in the EG for $19.4 \%$, in the CG - for 3.1\%' " $60 \mathrm{~m}$ run" - in the EG for $12.9 \%$, in the CG - for 9.4\%; "shuttle run $4 \times 9 \mathrm{~m}$ " - in the EG for $19.4 \%$, in the CG - for $6.3 \%$; "long jump from the place" - no changes occurred.

Table 3 The Ratio of Changes of Low Level of Competence by Pupils from the Experimental and Control Groups (after the experiment)

\begin{tabular}{|c|c|c|}
\hline Exercises & The EG pupils (\%) & The CG pupils (\%) \\
\hline “30m run (sec)” & $19.4 \%$ & $3.1 \%$ \\
\hline “60m run (sec)” & $12.9 \%$ & $9.4 \%$ \\
\hline “shuttle run 4x9m (sec)” & $19.4 \%$ & $6.3 \%$ \\
\hline “long jump from the place (cm)” & No changes & No changes \\
\hline
\end{tabular}

So, the results of implementation of author program of speediness development of secondary school children (11-12 years) with the priority use of 
Khanikiants et al., 2021. The Application of Athletics Tools in Due to Develop Speed of Secondary School Children

athletic tools prove its effectiveness and suggested methods, forms and tool of speediness development in the program is expedient to implement in the process of physical education of secondary school children.

\section{Conclusions}

In the process of investigation there was theoretically and experimentally justified effectiveness of the program of speediness development by secondary school children (11-12 years old) with priority use of athletic tools.

After implementation of author program, the statistically reliable $(\mathrm{p}<0.05)$ improvement occurred among pupils from the experimental group according to results of performing of such exercises as " $30 \mathrm{~m}$ run (sec)", " $30 \mathrm{~m}$ run from the spot (sec)" and "run at the spot during 5 seconds (movements quantity)". From the contrary, the statistically significant $(\mathrm{p}<0.05)$ improvement among pupils from the control group occurred only according to result of performed exercise "run at the spot during 5 seconds (movements quantity)".

The quantity of pupils with high level of competence has grown after implementation of author program in the experimental group according to results of such exercises as " $30 \mathrm{~m}$ run (sec)" - for 19.4\%; "long jump from the place (cm) - for 16.1\%; “60m run (sec)" - for 12.9\%; "shuttle run 4x9m (sec)" for $6.5 \%$.

The quantity of pupils from the experimental group, who demonstrated low level of competence, has decreased according to results of performing of such exercises as " $30 \mathrm{~m}$ run (sec)" - for $19.4 \%$; "60m run (sec)" - for $12.9 \%$; "shuttle run $4 \times 9 \mathrm{~m}$ (sec)" - for $19.4 \%$. The level of competence did not change in the exercise "long jump from the place $(\mathrm{cm})$ ".

The perspective of further researches might be directed to elaborate program for speediness development for secondary school girls, for pupils from special medical groups or individual programs to correct level of development of speediness and speed-power components of pupils.

\section{References}

Alabin, V., Zub, V. \& Mishhenko, A. (1993). 2000 uprazhnenij dlja legkoatletov. Harkiv: Osnova.

Drobin, B. (1990). Razvitie fizicheskih kachestv na urokah legkoj atletiki. Iz opyta raboty v 5 - 7 klassah. Fizicheskaja kul'tura v shkole, (7), 14-17.

Dubogaj, O. Pangelov, B. Frolova, \& Gorbenko M. (2001). Integracija piznaval'noï i ruhovoï dijal'nosti v sistemi navchannja i vihovannja shkoljariv. Kiïv: Orijani. Retrieved from: https://kopilkaurokov.ru/fizkultura/prochee/razvitiie-fizichieskikh-kachiestv-naurokakh-po-lieghkoi-atlietikie. 
Fedonjuk, Ja., Mickan, B. Popel', S., Fedonjuk, L., Dovgan', O., Borkovs'kij, V. \& Jushhak M. (2007). Funkcional'na anatomija. Ternopil': Navchal'na kniga - Bogdan.

Fizichna kul'tura v shkoli: navchal'na programa dlja 5 - 9 klasiv zagal'noosvitnih navchal'nih zakladiv. (2018). Kiïv: Litera LTD. Retrieved from: https://fizkulturamo.at.ua/load/ programmy_po_fizkulture/srednjaja_shkola/navchalna_programa_z_fizichnoji_kulturi_ dlja_zagalnoosvitnikh_navchalnikh_zakladiv_5_9_klasi/10-1-0-116

Halajdzhi, S., Jagotin, R., Lagovs'ka, N., \& Capenko, L. (2018). Navchannja tehniki bigu na korotki distanciï. Odesa: ONAHT.

Khanikiants, O., Konestyapin, V. \& Goliney, A. (2019). Specifics of quickness development of average school age pupils. IV International Eurasian Conference Sport Education and Society, International Juried Arts Mixed Exhibition on National Cultures. Denizli, TURKEY, 1422. Retrieved from: https://cutt.ly/ahN6yea

Khanikiants, O., Rymar, O., \& Konestyapin V. (2020). Udoskonalennja shvidkisno-silovoï pidgotovki uchniv seredn'ogo shkil'nogo viku iz prioritetnim vikoristannjam zasobiv legkoatletichnih stribkiv. Inovacijna pedagogika, (Specvipusk), 74-78. DOI: https://doi.org/10.32843/2663-6085/2020/22-4.16

Konestyapin, V. \& Viter, T. (2008). Fizichne vihovannja shkoljariv 14-15 rokiv z prioritetnim vikoristannjam zasobiv legkoï atletiki. Moloda sportivna nauka Ukraïni, 2 (12), 115119. Retrieved from: https://cutt.ly/fhN5NLk

Krucevich, T. (2008). Teorija i metodika fizichnogo vihovannja. Kiïv Olimpijs'ka literatura.

Kushmeljuk, V. \& Kushmeljuk, A. (2007). Special'ni vpravi dlja navchannja ta trenuvannja legkoatletiv. Ivano-Frankivs'k: Koledzh fizichnogo vihovannja.

Linec', M. (1997). Osnovi metodiki rozvitku ruhovih jakostej : L'viv: Shtabar.

Mandiuk, A., Yaroshyk, M. \& Litkevich O. (2014). Porivnjal'nij analiz testiv rivnja fizichnoï pidgotovlenosti v Ukraïni ta zarubizhnih kraïnah. Slobozhans'kij naukovo-praktichnij visnik, №2 (40), 90-94. Retrieved from: file://C:/Users/hp/Downloads/24494-41687-1PB\%20(1).pdf

Rymar, O., \& Khanikiants, O. (2020). Ocinka silovih ta shvidkisno-silovih jakostej uchniv seredn'ogo shkil'nogo viku. Naukovij chasopis NPU im. M.P. Dragomanova, (3K (123) 20), 364-371. Retrieved from: https://cutt.ly/AhN6dRx

Semenov, A., Osadchenko, T., Maєvs'kij, M., \& Il'chenko, S. (2014). Legka atletika z metodikoju vikladannja. Uman': Vizavi.

Sorokolit, N., Shyan, O., Lukjanchenko, M. \& Turchyk, I. (2017). Improvement of 5-9th Grades Schoolchildren Physical Education in Ukraine by Using Variable Modules Curriculum. Journal of Physical Education and Sport, (17), Supplement issue 4, 21102115. DOI: https://doi.org/10.7752/jpes.2017.s4215

Shyan, B. (2004). Teorija i metodika fizichnogo vihovannja shkoljariv. Ternopil': Navch. Kniga - Bogdan.

Zavydivska, O., Zavydivska, N., Khanikiants, O. \& Rymar, O. (2017). The paradigm of health maintenance at Higher Education Institutions as an Important Component of Human Development in Terms of Modernity. Journal of Physical Education and Sport, (17), Supplement Issue 1, 60 - 65. DOI: https://doi.org/10.7752/jpes.2017.s1009 